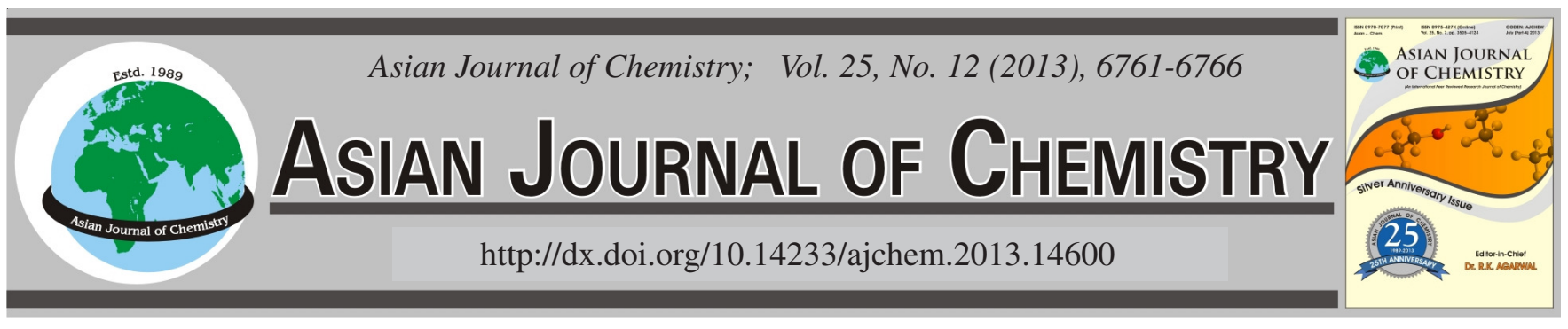

\title{
Characterization of Cellulases of Thermopiles Bacteria from Rimbo Panti Hot Spring, West Sumatera, Indonesia
}

\author{
Armaini $^{1}$, Abdi Dharma ${ }^{1, *}$, Edison MunaF $^{2}$, Sumaryati Syukur $^{1}$ and JAmSARI ${ }^{3}$
}

\begin{abstract}
${ }^{1}$ Biochemistry Laboratory, Department of Chemistry, Faculty of Mathematics and Natural Sciences, Andalas University, Padang 25163, Indonesia ${ }^{2}$ Environmental Analytical Chemistry Laboratory, Department of Chemistry, Faculty of Mathematics and Natural Sciences, Andalas University, Padang 25163, Indonesia
\end{abstract}

${ }^{3}$ Faculty of Agriculture, Andalas University, Padang 25163, Indonesia

*Corresponding author: E-mail: abdi11750@yahoo.co.id

(Received: 21 September 2012;

Accepted: 31 May 2013)

AJC-13566

\begin{abstract}
The thermopiles bacteria from hot springs Rimbo Panti, West Sumatera, Indonesia was screened. Screening is done by using a selection medium for thermopiles bacteria and to examine the potential of cellulases used medium containing carboxy methyl cellulose and stained with Congo red which marked the formation of clear zones, where the isolates obtained was 14 . In this study, the effect of temperature and $\mathrm{pH}$ on endoglucanases activity showed that, it is thermo-tolerant enzyme because at the temperature from $50-100{ }^{\circ} \mathrm{C}$ still show a fairly stable and increas the activity up to $100^{\circ} \mathrm{C}$, with the tolerant of $\mathrm{pH}$ ranging from $\mathrm{pH} 4.8$ to 7.5 . The three isolates were also thermo-stable at temperatures 70 to $100{ }^{\circ} \mathrm{C}$. Maximum activity of exoglucanases produced by the $1 \mathrm{M}-2$ isolates sample is $40.20 \mathrm{units} / \mathrm{mg}$ at $70{ }^{\circ} \mathrm{C}$ and $\mathrm{pH}$ 6.5, on the other hand, the highest maximum activity of endoglucanases produced by, isolates $1 \mathrm{M}-3$ is $70.50 \mathrm{units} / \mathrm{mg}$, at optimum conditions of temperature $100{ }^{\circ} \mathrm{C}$ and $\mathrm{pH}$ 7.5. Moreover, the highest maximum activity of $\beta$-glucosidases produced by, $1 \mathrm{M}-2$ isolates is 65.30 units/mg at temperature $80{ }^{\circ} \mathrm{C}$ and $\mathrm{pH} 7.5$.
\end{abstract}

Key Words: Thermopiles bacteria, Exoglucanases, Endoglucanases, $\beta$-Glucosidases.

\section{INTRODUCTION}

Celulolytic enzyme is responsible for hydrolytic cleavage of $\beta$-glycosidic bond in cellulose polymer to release glucose units ${ }^{1,2}$. They can be broadly classified into three types based on their mode of action: (a) endoglucanases or carboxymethyl cellulases (CMCases) (endo-1,4-glucanasa, EC. 3.2.1.4), bring out hydrolysis of internal glycosidic bonds in cellulose chains, creating more terminal ends in the fragment, (b) exoglucanases or cellobiohydrolases (exo-1,4-glucanases, EC. 3.2.1.91) liberate glucose or cellobiose from end of cellulose chains/fragment due to hydrolysis of terminal glycosidic bonds and (c) $\beta$-1,4-glucosidases ( $\beta$-D-glucohydrolases, EC. 3.2.1.21) was hydrolysis cellobiose formed as a result of synergic action of the above two enzymes ${ }^{3-6}$. Bacteria, due to their high diversity, faster growth and capability to produce highly thermo-stable enzymes, are ideal to be used in industries as highly potent and robust sources of industrially important enzymes ${ }^{7}$. Degradation of cellulose at elevated temperature provides many benefits, such as increased cellulase activity, lessened energy costs for cooling and decreased risk of contamination ${ }^{8}$. Thermostable cellulase has high-level activity under thermal conditions. Thus, it is an attractive candidate for practical applications ${ }^{9}$.
Assays for determining cellulase activity have been classified differently over years of cellulase research. Sharrockc ${ }^{10}$ grouped cellulase assays into two basic approaches, namely activities of individual cellulases (EGs, exoglucanases and $\beta$ glucosidases) and measuring the total saccharifying activity of a crude cellulase system. Cellulase activity is mainly evaluated using a reducing sugar assay to measure the end products of cellulase hydrolysis activities. More over, the results of such an assay are typically expressed as the hydrolysis capacity of the enzymes. The present work reported the characterization of cellulases of thermopiles bacteria screened from Rimbo Panti Hot Spring, West Sumatera, Indonesia.

\section{EXPERIMENTAL}

The materials used for this study were in analytical grade. Carboxyl methyl cellulose (CMC), $0.05 \mathrm{~mol} / \mathrm{L}$ citrate buffer pH 4.8 Avicell (microcrystalline cellulose), $0.05 \mathrm{~mol} / \mathrm{L}$ sodium acetate buffer ( $\mathrm{pH} 4.5$ ), glucose, 3.5 di-nitro salicylic acid (DNS) reducing sugar reagent, Glucostat 4X Reagent Set (Worthington Biochemical Corporation, USA), cellobiose, Bio Rad Protein Assay (Commassie Brilliant Blue G-250), $\left(\mathrm{NH}_{4}\right)_{2} \mathrm{SO}_{4}$, phosphate buffer ( $\left.\mathrm{pH} 7.5\right)$. 
The medium selection for thermopiles bacteria, to the volume of $1 \mathrm{~L}$ are: tryptone, yeast extract, $\mathrm{CaCl}_{2}$, galerite gallen gum, agar, vitamin $1 \%(\mathrm{v} / \mathrm{v}$ ) (consisting of pyridoxine $0.01 \mathrm{~g}$, $0.05 \mathrm{~g}$ nicotinic acid, thiamine $0.05 \mathrm{~g}, 0.02 \mathrm{~g}$ biotin dissolved in $100 \mathrm{~mL}$ of distilled water, filtered with filter $0.2 \mathrm{~m}$ ) and minerals, $1 \%$ (v/v) (consisting of $\mathrm{MgSO}_{4} \cdot 7 \mathrm{H}_{2} \mathrm{O} 0.3 \mathrm{~g}, \mathrm{MnSO}_{4} \cdot \mathrm{H}_{2} \mathrm{O}$ $12.5 \mathrm{~g}, \mathrm{FeSO}_{4} \cdot 7 \mathrm{H}_{2} \mathrm{O} 0.01 \mathrm{~g}, \mathrm{CoCl}_{2} 0.01 \mathrm{~g}, \mathrm{ZnSO}_{4} \cdot 7 \mathrm{H}_{2} \mathrm{O} 0.01$ $\mathrm{g}, \mathrm{CuSO}_{4} \cdot 5 \mathrm{H}_{2} \mathrm{O} 0.01 \mathrm{~g}$ dissolved in $100 \mathrm{~mL}$ distilled water), medium adjusted to $\mathrm{pH} 8$ with $\mathrm{CaCO}_{3}$.

Medium composition for the formation of clear zone as follows for the volume of $1 \mathrm{~L}: 2 \mathrm{~g}$ ammonium sulphate, $2 \mathrm{~g}$ $\mathrm{KH}_{2} \mathrm{PO}_{4}, 0.3 \mathrm{~g}$ urea, $0.3 \mathrm{~g} \mathrm{CaCl}_{2}, \mathrm{NaCl} 0.1 \mathrm{~g}, \mathrm{FeSO}_{4} \cdot 7 \mathrm{H}_{2} \mathrm{O} 5$ $\mathrm{mg}, 1.4 \mathrm{mg} \mathrm{MnSO}_{4} \cdot 7 \mathrm{H}_{2} \mathrm{O}, 2 \mathrm{mg} \mathrm{CoCl}_{2}, \mathrm{CMC} 1.5 \mathrm{~g}, 4 \mathrm{~g}$ peptone, $15 \mathrm{~g}$ bacto-agar sterilized medium.

High pressure steam sterilizer BS-245, Water Bath-Shaker Taitex. Personal-11, Clean Bench . Hitachi, UV-1600, UV-VIS spectrophotometre Shimadzu, pH Messer model 80 Griffin (Griffin \& George Southborough, UK) and glassware commonly used laboratory.

Screening of thermophilic bacteria: Screening performed on water samples from hot springs Rimbo Panti, West Sumatra, Indonesia using the selection medium for thermopiles bacteria, is done by pouring the water sample $(5 \mathrm{~mL})$ into Petri, then poured medium selection. In a Petri disc containing the selection medium and hot water sample will grow colonies of thermopiles bacteria after incubation at $70{ }^{\circ} \mathrm{C}$ for 2 days and $50{ }^{\circ} \mathrm{C}$ for 3 days. Each colony was separated and grown on selection medium to obtain single colonies on each Petri's at the same incubation temperature. The separation of the colonies continued until single colony of isolates obtained in each Petri.

Determination of potential cellulase activity: Cellulase activity observed with the formation of clear zone using a medium formation of clear zone, containing carboxy methyl cellulose and with Congo red dye, Cultivate every single isolates into each dish and incubation at $50{ }^{\circ} \mathrm{C}$ for 2 days, measure the diameter of the colony of thermopiles bacteria and then flooding medium surface with Congo red $0.1 \%(\mathrm{v} / \mathrm{v})$ left for $5 \mathrm{~min}$ and faded with $1 \mathrm{~mol} / \mathrm{L} \mathrm{NaCl}$, it would seem clear zone around thermopiles bacterial colonies. Halo diameters were measured and compared between all isolates.

Isolation of enzymes: Thermopiles bacteria were grown in liquid medium with the composition of the medium as follows for the volume of $1 \mathrm{~L}: 2 \mathrm{~g}$ ammonium sulphate, $2 \mathrm{~g}$ $\mathrm{KH}_{2} \mathrm{PO}_{4}, 0.3 \mathrm{~g}$ urea, $0.3 \mathrm{~g} \mathrm{CaCl}, \mathrm{NaCl} 0.1 \mathrm{~g}, \mathrm{FeSO}_{4} \cdot 7 \mathrm{H}_{2} \mathrm{O}$ $5 \mathrm{mg}, 1.4 \mathrm{mg} \mathrm{MnSO}_{4} \cdot 7 \mathrm{H}_{2} \mathrm{O}, \mathrm{CoCl}_{2} 2 \mathrm{mg}, \mathrm{CMC} 1.5 \mathrm{~g}, 4 \mathrm{~g}$ peptone. Medium (100 mL), poured into Erlenmeyer flasks $(250 \mathrm{~mL})$, sterilized and inoculated bacterial culture into it and then incubated in a water bath, shaker at $150 \mathrm{rpm}$ with temperature $50{ }^{\circ} \mathrm{C}$ for $48 \mathrm{~h}$. Separate the cells and supernatant in a centrifuge at a speed of $10,000 \mathrm{rpm}$ for $10 \mathrm{~min}$, take supernatant. Supernatant was precipitated with ammonium sulphate (80\% saturation), all steps performed at $4{ }^{\circ} \mathrm{C}$. The precipitate was re-suspended in phosphate buffer $(10 \mathrm{mmol} /$ $\mathrm{L}), \mathrm{pH} 7.5$, then dialysis in $3 \mathrm{~L}$ of the same buffer for $36 \mathrm{~h}$ by replacing the buffer three times every $12 \mathrm{~h}$. Supernatant is to be tested cellulase enzyme activity.

Assay of exoglucanase activity: Activity was measured using the method of Ghosh ${ }^{11}$ with commercial Avicell (micro- crystalline cellulose) as substrate; avicell suspension (1\%) $(\mathrm{w} / \mathrm{v})$ in $0.05 \mathrm{~mol} / \mathrm{L}$. Sodium acetate buffer $\mathrm{pH} 4.5$ and using glucose as standard. Exoglucanase enzyme activity assay, using $1 \mathrm{~mL}$ of liquid culture containing enzymes exoglucanase put into test tubes $(25 \mathrm{~mL})$ add $1 \mathrm{~mL}$ of substrate avicell shake with vortex and then incubated for $1 \mathrm{~h}$ at $50{ }^{\circ} \mathrm{C}$ in a water bath-shaker. The reaction was stopped with $3 \mathrm{~mL}$ of DNS reagent shake with vortex and the test tubes is inserted into the boiling water for 5-10 min then cool in ice water (ice bath) and add $20 \mathrm{~mL}$ of distilled water, shake with vortex and measuring with a spectrophotometer at $540 \mathrm{~nm}$.

Assay of endoglucanases activity: Activity was measured using the method of Ghosh ${ }^{11}$ is based on measuring the liberated reducing sugars as a result of degradation of cellulose. Substrate used was carboxy methyl cellulose (2\%), dissolved in $0.05 \mathrm{~mol} / \mathrm{L}$ citrate buffer $\mathrm{pH} 4.8$ and used glucose as standard. Cellulase enzyme activity assay performed using 0.5 $\mathrm{mL}$ of liquid culture containing cellulase enzyme is inserted into a test tube $(25 \mathrm{~mL})$ was added $0.5 \mathrm{~mL}$ carboxy methyl cellulose substrate, shaken by vortex and then incubated for $0.5 \mathrm{~h}$ at $50^{\circ} \mathrm{C}$ in a water bath-shaker. The reaction was stopped with $3 \mathrm{~mL}$ of DNS reagent shake with vortex and the test tubes is inserted into the boiling water for 5-10 min then cool in ice water (ice bath) and add $20 \mathrm{~mL}$ of distilled water, shake with vortex and measuring with a spectrophotometer at $540 \mathrm{~nm}$. Cellulase activity is expressed 1 unit $=1.0$ mol glucose released from cellulose per minute (incubation time, $0.5 \mathrm{~h}$ and temperature $50{ }^{\circ} \mathrm{C}$ ).

Assay of $\boldsymbol{\beta}$-glucosidases activity: Activity was measured using the method of Mandel ${ }^{12}$ with glucostat $4 \mathrm{X}$ reagent set (Worthington Biochemical Corporation) USA and cellobiose as substrate. To prepare the reagents; 1 bottle glucostat, dissolved in $160 \mathrm{~mL}$ of distilled water (store in refrigerator) and 1 bottle chromagen dissolved in $160 \mathrm{~mL}$ of distilled water (store in refrigerator), mix glucostat and chromagen with a ratio of 1:1 used in fresh condition. Dissolve $20 \mathrm{mmol} / \mathrm{L}$ cellobiose $(684 \mathrm{mg} / 100 \mathrm{~mL})$ in $0.05 \mathrm{~mol} / \mathrm{L}$ citrate buffer, $\mathrm{pH}$ 4.5 and the standard use of glucose. Assay of $\beta$-glucosidase enzyme activity using $1 \mathrm{~mL}$ of liquid culture containing $\beta$-glucosidase enzyme is inserted into the test tube $25 \mathrm{~mL}$ add $1 \mathrm{~mL}$ of substrate cellobiose $(20 \mathrm{mmol} / \mathrm{L})$ was shaken with a vortex and then incubated for $0.5 \mathrm{~h}$ at $50{ }^{\circ} \mathrm{C}$ in a water bathshaker, then the reaction tube is inserted into the boiling water for $5 \mathrm{~min}$ then cool and add $5 \mathrm{~mL}$ of reagent glucostat on each tube at intervals of $20 \mathrm{~s}$ with a vortex shake allow $10 \mathrm{~min}$, add 4 drops of $5 \mathrm{~mol} / \mathrm{L} \mathrm{HCl}$ shake vortex leave $5 \mathrm{~min}$ and measured by spectrophotometer at $420 \mathrm{~nm}$.

Effect of temperature and $\mathrm{pH}$ activity against exoglucanase, endoglucanase and $\boldsymbol{\beta}$-glucosidase: Effect of temperature on the activity carried out by, incubation temperature variations of $37,40,50,60,70,80,90$ and $100^{\circ} \mathrm{C}$ with an incubation time $0.5 \mathrm{~h}$ and $\mathrm{pH} 4.8$. Effect of $\mathrm{pH}$ on the enzyme activity carried out by variation of $\mathrm{pH}$ from 4 to 8 with an incubation time of $0.5 \mathrm{~h}$ at $50{ }^{\circ} \mathrm{C}$.

Determination of cellulases protein: Protein of cellulases was determined by Bio Rad Protein Assay (Commassie Brilliant Blue G-250). The assay is based on the method of Bradford ${ }^{13}$. In this assay BSA was used as a standard, $0.1 \mathrm{~mL}$ filtrate enzyme is added $5 \mathrm{~mL}$ of Bio Rad reagent mixture with vortex 
and then incubated for $5 \mathrm{~min}$ at room temperature. Measured by spectrophotometer in $595 \mathrm{~nm}$.

\section{RESULTS AND DISCUSSION}

Enzyme activity of cellulase: Activity of exoglucanase, endoglucanase and $\beta$-glucosidase obtained from 14 isolates, respectively from 2.74 to 18.23 units/mg for exoglucanase, 6.64 to 58.40 units/mg for endoglucanase, 3.56 to 49.8 units/ $\mathrm{mg}$ for $\beta$-glucosidase at standard conditions of assay, protein content and glucose released from cellulose per minute as shown in Table-1. The result shows that the activity is lower than endoglucanase exoglucanase and $\beta$-glucosidase. In Fig. 1, enzymes activity exoglucanase, endoglucanase and $\beta$-glucosidase of 14 isolates found 6 isolates that have high activity as compared with pure cellulase from Aspergillus niger. Then to the effect of temperature and $\mathrm{pH}$ was performed in 6 isolates.

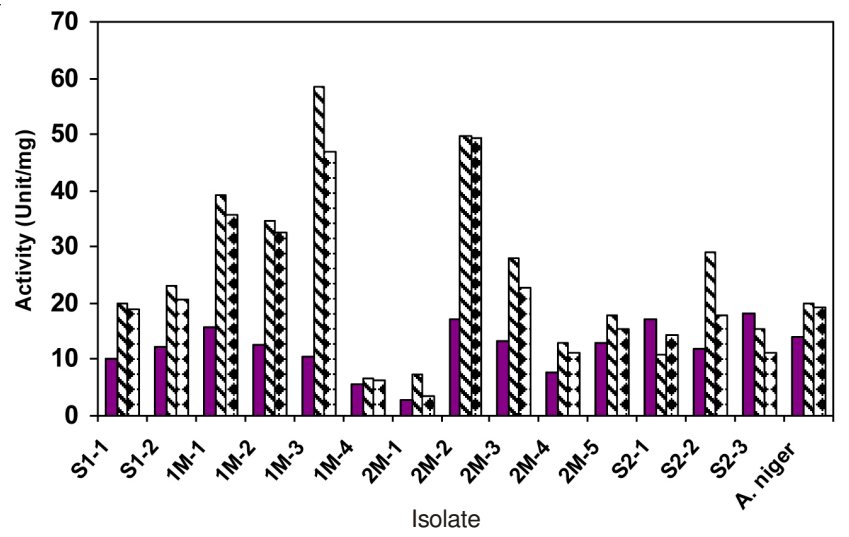

- Exo-cellulase $\mathbf{v}$ Endo-cellulase $\boldsymbol{\nabla} \beta$-Glucosidase

Fig. 1. Activity of, enzymes exoglucanase, endoglucanase and $\beta$ glucosidase from 14 isolates of thermophilic bacteria at standard condition, for exo-glucanase (temperature $50{ }^{\circ} \mathrm{C}$. $\mathrm{pH} 4.5$, acetate buffer, incubation time $1 \mathrm{~h}$ ), for endoglucanase (temperature $50{ }^{\circ} \mathrm{C}$, $\mathrm{pH} 4.8$, buffer citrate and incubation time $0.5 \mathrm{~h}$ ) and for $\beta$ glucosidase (temperature $50^{\circ} \mathrm{C}, \mathrm{pH} 4,5$, citrate buffer and incubation time $0.5 \mathrm{~h}$ )
Effects of temperature and $\mathrm{pH}$ on activity exoglucanases: Effects of temperature and $\mathrm{pH}$ on the activity exoglucanase are shows in Fig. 2A-B. As shown in Fig. 2A-B, from isolate thermophilic bacterial, 6 isolates, i.e., shows high activity compared with the cellulase from Aspergillus niger, with a maximum activity 35.43, 38.90, 40.20 and 35.05 units/mg, respectively. Temperature and $\mathrm{pH}$ optimum for $1 \mathrm{M}-1$ isolates are $80^{\circ} \mathrm{C}$ and $\mathrm{pH} 7$ with maximum activity of 35.08 units $/ \mathrm{mg}$. Moreover for $2 \mathrm{M}-2$ isolates the optimum temperature and $\mathrm{pH}$ are, $60{ }^{\circ} \mathrm{C}$ and 6.0 with maximum activity of 32.65 units $/ \mathrm{mg}$. The maximum activity for exoglucanase produced by the $1 \mathrm{M}$ 2 isolates is 40.20 units/mg at optimum conditions. The results shows higher than the pure enzyme from Aspergillus niger, with maximum activity of 37.85 units $/ \mathrm{mg}$ at the optimum temperature $50{ }^{\circ} \mathrm{C}$ and $\mathrm{pH}$ 7. The comparation of production formation rate for both exoglucanase and endoglucanase from mutant and parent Bacillus subtilis GQ301542 were (41.5 and 65.5 IU/L/h) and (18.50 and 48.00 IU/L/h), respectively.
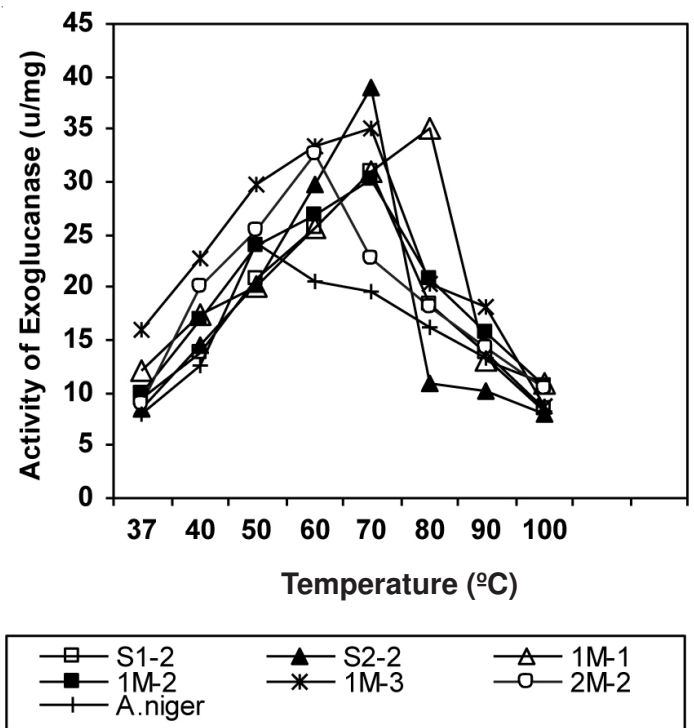

A

\begin{tabular}{|c|c|c|c|c|c|c|c|c|c|c|c|}
\hline \multirow{4}{*}{ No. } & \multicolumn{10}{|c|}{$\begin{array}{l}\text { TABLE-1 } \\
\text { ED GLUCOSE, ACTIVITY OF ENDOGLUCANASE, } \\
\text { SE FROM ISOLATES OF THERMOPHILIC BACTERIA }\end{array}$} & \\
\hline & \multirow{3}{*}{$\begin{array}{l}\text { Code } \\
\text { isolate }\end{array}$} & \multicolumn{4}{|c|}{ Endoglucanase } & \multicolumn{3}{|c|}{ Exoglucanase } & \multicolumn{3}{|c|}{$\beta$-Glucosidase } \\
\hline & & \multirow{2}{*}{$\begin{array}{l}\text { Protein } \\
(\mathrm{mg})\end{array}$} & \multirow{2}{*}{$\begin{array}{l}\text { Glucose } \\
\text { (mg) }\end{array}$} & \multicolumn{2}{|c|}{ Activity } & \multirow{2}{*}{$\begin{array}{c}\text { Glucose } \\
\text { (mg) }\end{array}$} & \multicolumn{2}{|c|}{ Activity } & \multirow{2}{*}{$\begin{array}{l}\text { Glucose } \\
(\mathrm{mg})\end{array}$} & \multicolumn{2}{|c|}{ Activity } \\
\hline & & & & Unit & $\mathrm{U}(\mathrm{mg})$ & & Unit & $\mathrm{U}(\mathrm{mg})$ & & Unit & $\mathrm{U}(\mathrm{mg})$ \\
\hline 1 & $\mathrm{~S} 1-1$ & 0.040 & 2.150 & 0.795 & 19.75 & 8.984 & 0.832 & 20.81 & 8.099 & 0.750 & 18.75 \\
\hline 2 & $\mathrm{~S} 1-2$ & 0.034 & 2.114 & 0.782 & 23.00 & 9.287 & 0.860 & 25.30 & 7.589 & 0.703 & 20.67 \\
\hline 3 & $1 \mathrm{M}-1$ & 0.013 & 1.372 & 0.507 & 39.49 & 4.806 & 0.445 & 34.24 & 5.000 & 0.463 & 35.65 \\
\hline 4 & $1 \mathrm{M}-2$ & 0.021 & 1.970 & 0.729 & 34.14 & 6.792 & 0.629 & 29.95 & 9.330 & 0.864 & 32.59 \\
\hline 5 & $1 \mathrm{M}-3$ & 0.015 & 2.368 & 0.876 & 58.40 & 7.192 & 0.666 & 44.40 & 7.591 & 0.703 & 46.86 \\
\hline 6 & $1 \mathrm{M}-4$ & 0.110 & 2.004 & 0.731 & 6.64 & 6.501 & 0.602 & 5.46 & 7.289 & 0.675 & 6.13 \\
\hline 7 & $2 \mathrm{M}-1$ & 0.109 & 2.172 & 0.804 & 7.37 & 3.228 & 0.299 & 2.74 & 4.190 & 0.388 & 3.56 \\
\hline 8 & $2 \mathrm{M}-2$ & 0.009 & 1.210 & 0.447 & 49.66 & 3.596 & 0.333 & 37.00 & 4.794 & 0.444 & 49.38 \\
\hline 9 & $2 \mathrm{M}-3$ & 0.009 & 1.664 & 0.615 & 27.95 & 3.196 & 0.296 & 13.45 & 4.848 & 0.449 & 22.70 \\
\hline 10 & $2 \mathrm{M}-4$ & 0.050 & 1.752 & 0.648 & 12.96 & 4.157 & 0.385 & 7.69 & 5.993 & 0.555 & 11.10 \\
\hline 12 & S2-1 & 0.072 & 2.146 & 0.794 & 11.02 & 3.412 & 1.242 & 17.25 & 11.285 & 1.045 & 14.52 \\
\hline 13 & S2-2 & 0.025 & 1.956 & 0.724 & 28.96 & 8.736 & 0.809 & 32.39 & 4.794 & 0.444 & 17.76 \\
\hline 14 & S2-3 & 0.059 & 2.480 & 0.917 & 15.54 & 11.608 & 1.075 & 18.23 & 7.084 & 0.656 & 11.13 \\
\hline 15 & A niger & 0.021 & 1.140 & 0.422 & 20.09 & 3.196 & 0.296 & 14.09 & 4.395 & 0.407 & 19.38 \\
\hline
\end{tabular}




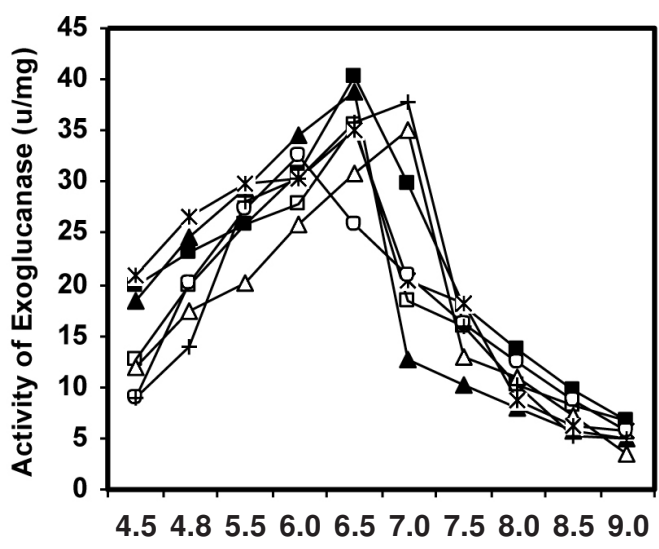

$\mathrm{pH}$

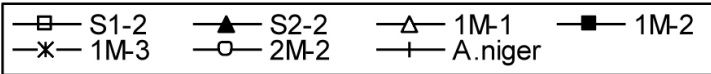

$B$

Fig. 2. Temperature (A) and $\mathrm{pH}(\mathrm{B})$ optimum. Exoglucanase activity were assayed (A) in acetate buffer $\mathrm{pH} 4.5$ at $37-100{ }^{\circ} \mathrm{C}$ and (B) at optimum temperature and $\mathrm{pH}$ various of 4.5-9.0 used acetate buffer ( $\mathrm{pH}$ 4.5-5.0), phosphate buffer ( $\mathrm{pH}$ 6.0-7.5) and Tris/HCl buffer ( $\mathrm{pH} 8-9)$, for 6 isolates that have high activity compared with $A$. niger

Effects of temperature and $\mathrm{pH}$ on the activity of endoglucanases: Effects of temperature and $\mathrm{pH}$ on the activity of endoglucanases, showed that enzymes from thermophilic bacteria endoglucanases is thermo-tolerant, because at the temperature of $50-100{ }^{\circ} \mathrm{C}$ still show a fairly stable activity in the isolates. On the other hand, sample no. $1 \mathrm{M}-1,1 \mathrm{M}-2$ and $1 \mathrm{M}-3$, show an increase in activity up to $100{ }^{\circ} \mathrm{C}$ (Fig. $3 \mathrm{~A}$ ). Endoglucanases are tolerant of $\mathrm{pH}$ ranging from $\mathrm{pH} 4.8$ to 7.5 for consecutive isolates $1 \mathrm{M}-1,1 \mathrm{M}-2$ and $1 \mathrm{M}-3$ and tolerant at $\mathrm{pH}, 4.8$ to 7.0 for the isolates, $2 \mathrm{M}-3,2 \mathrm{M}-4$ and $\mathrm{S} 2-2$, respcctively (Fig. 3B). The optimum conditions of 6 isolates is as follows: isolate $1 \mathrm{M}-1,1 \mathrm{M}-2$ and $1 \mathrm{M}-3$ having a maximum activity at $100^{\circ} \mathrm{C}$ and $\mathrm{pH} 7.5$, namely $62.30,60.50$ and 70.50 units $/ \mathrm{mg}$, respectively. For $2 \mathrm{M}-2$ and $2 \mathrm{M}-3$ isolates, the maximum activity are 58.85 and 40.32 units $/ \mathrm{mg}$ at $70{ }^{\circ} \mathrm{C}$ and $\mathrm{pH}$ 7. S2-2 isolates reach a maximum activity, i.e., 58.25 units/mg at $80{ }^{\circ} \mathrm{C}$ and $\mathrm{pH}$ 7.0. Furthermore, the highest activity of endoglucanase produced by isolates $1 \mathrm{M}-3$ is 70.50 units/mg. compared with the pure enzyme from Aspergillus niger with maximum activity of 48.20 units $/ \mathrm{mg}$ at $40{ }^{\circ} \mathrm{C}$ and $\mathrm{pH} 7$.

Endoglucanases from Bacillus pumilus EB3 $3^{14}$, was reported to have the highest maximum activity of 0.079 units/ $\mathrm{mL}$ at optimum temperature of $60^{\circ} \mathrm{C}$ and $\mathrm{pH}$ 6.0. Bacillus licheniformis WBS1 and Bacillus sp WBS $3^{15}$ have maximum activity of $0.118 \mathrm{IU} / \mathrm{mL}$ (optimum temperature $60^{\circ} \mathrm{C}$ and $\mathrm{pH}$ 8.0) and $0,088 \mathrm{IU} / \mathrm{mL}$ (optimum temperature $60^{\circ} \mathrm{C}$ and $\mathrm{pH}$ 9.0), respectively. The optimum temperature and $\mathrm{pH}$ for $\mathrm{rEglA}$ from A niger VTCC-F021 in Pichia pastoris activity were 55 ${ }^{\circ} \mathrm{C}(22.39 \mathrm{U} / \mathrm{mL})$ and $\mathrm{pH} 6.5^{16}$.

Effects of temperature and $\mathrm{pH}$ on $\boldsymbol{\beta}$-glucosidases activity: Effects of temperature and $\mathrm{pH}$ on the activity of $\beta$ glucosidase, from 6 isolates of thermophilic bacteria have a higher activity than the cellulase from Aspergillus niger, respectively, S1-2, 1M-1, 1M-2, 1M-3, 2M-2 and 2M-3. Optimum
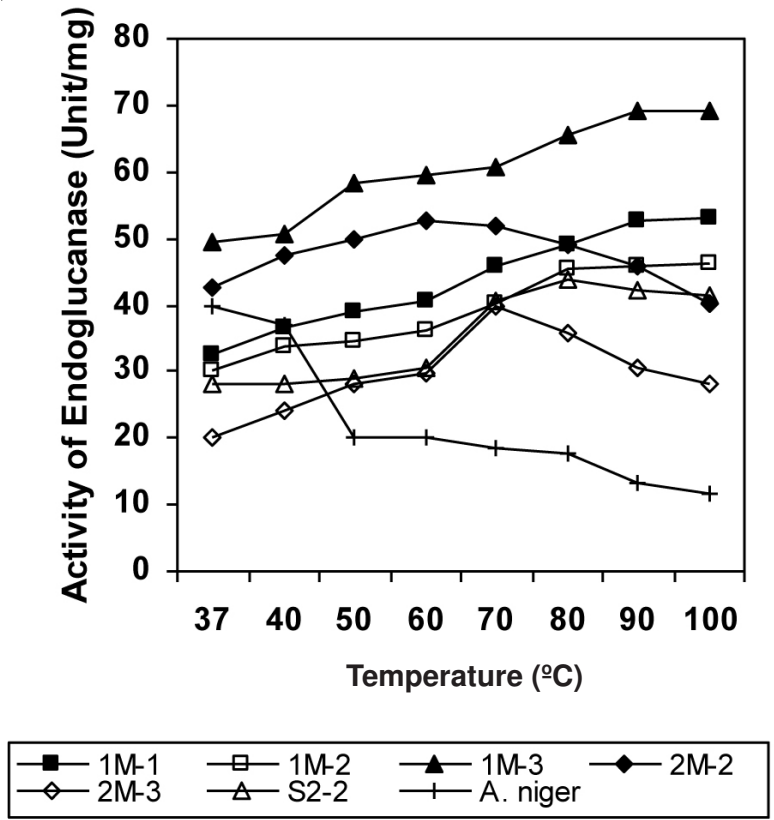

A

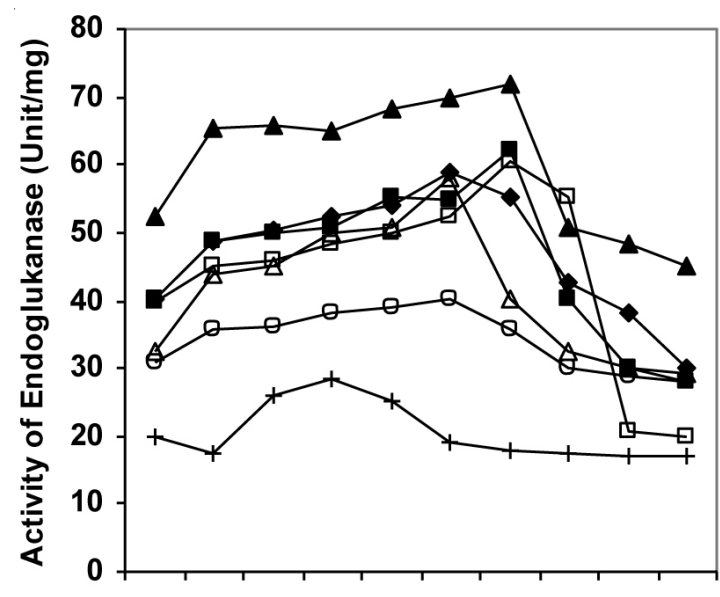

$4.54 .85 .56 .06 .57 .07 .5 \quad 8.0 \quad 8.5 \quad 9.0$

$\mathrm{pH}$

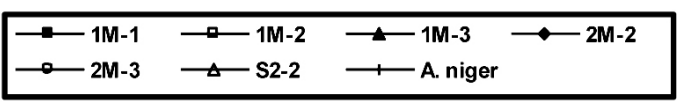

B

Fig. 3. Temperature (A) and $\mathrm{pH}(\mathrm{B})$ optimum. Endoglucanase activity were assayed (A) in citrate buffer $\mathrm{pH} 4.8$ at $37-100^{\circ} \mathrm{C}$ and (B) at optimum temperature and $\mathrm{pH}$ various of 4,5 -9, used citrate buffer ( $\mathrm{pH} 4.5$ 5.0), phosphate buffer $(\mathrm{pH}$ 6.0-7.5) and Tris/ $\mathrm{HCl}$ buffer $(\mathrm{pH} \mathrm{8-9)}$, for 6 isolates that have high activity compared with A. niger

conditions of the isolates S1-2 and $1 \mathrm{M}-1$ temperature of $80^{\circ} \mathrm{C}$ and $\mathrm{pH} 7$ with maximum activity respectively 58.06 and 55.83 units/mg. Condition optimum for $1 \mathrm{M}-2$ isolates and $1 \mathrm{M}-3$ at $80{ }^{\circ} \mathrm{C}$ and $\mathrm{pH} 7,5$ with maximum activity 61.8 and 65.3 units/ $\mathrm{mg}$, respectively. $2 \mathrm{M}-2$ isolates and $2 \mathrm{M}-3$, the optimum temperature of $70{ }^{\circ} \mathrm{C}$ and $\mathrm{pH} 6.5$ with maximum activity 62.60 and 45.50 units/mg (Fig. 4A-B). The highest maximum activity of $\beta$-glucosidase produced by the, $1 \mathrm{M}-3$ isolates is 65.30 units/ $\mathrm{mg}$ at optimum conditions. This results higher than the pure enzyme from Aspergillus niger with maximum activity of 48.20 units/mg at $37{ }^{\circ} \mathrm{C}$ and $\mathrm{pH}$ 7. The maximum activity 

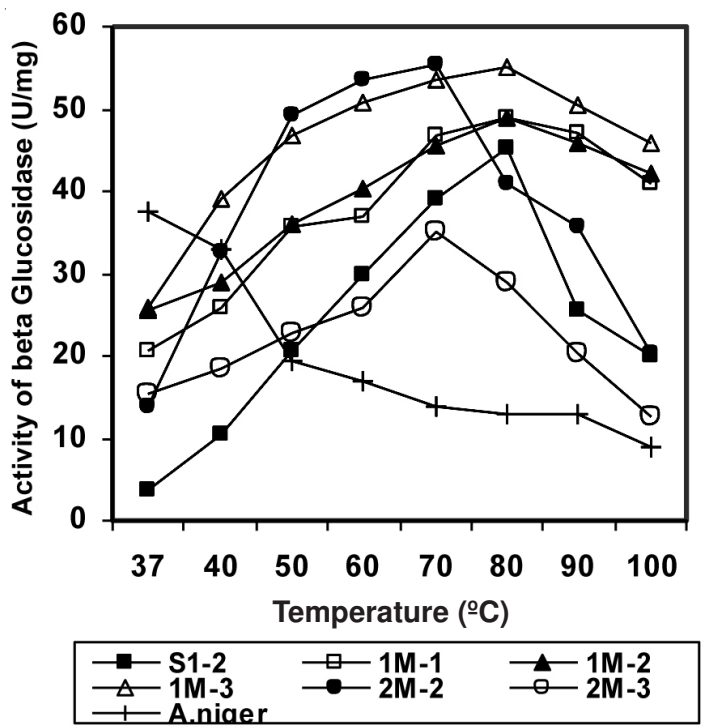

A
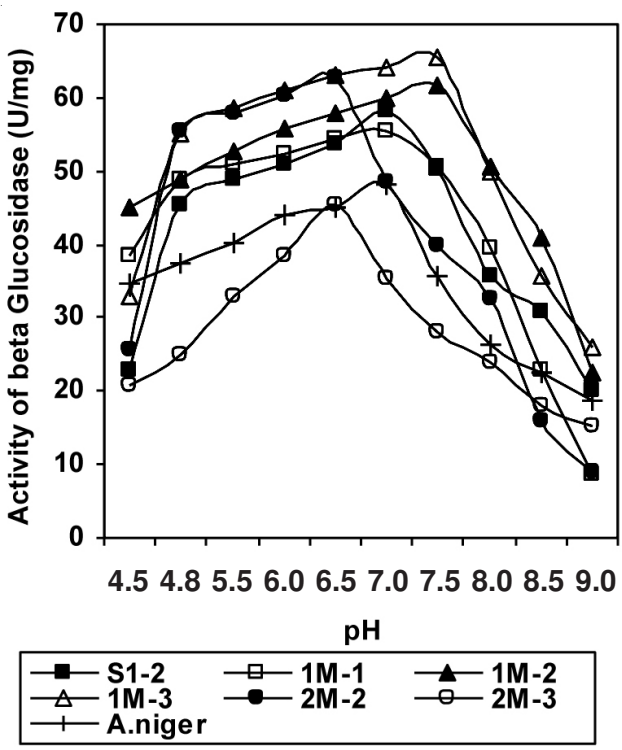

B

Fig. 4. Temperature (A) and $\mathrm{pH}(\mathrm{B})$ optimum. $\beta$-Glucosidase activity were assayed (A) in citrate buffer $\mathrm{pH} 4.5$, at $37-100^{\circ} \mathrm{C}$ and (B) at optimum temperature and $\mathrm{pH}$ various of 4,5 -9 used citrate buffer $(\mathrm{pH} 4.5-$ 5.0), phosphate buffer ( $\mathrm{pH}$ 6.0-7.0) and Tris/HCl buffer ( $\mathrm{pH} 7.5-8)$, for 6 isolates that have high activity compared with A. niger

of endoglucanase, higher than exoglucanase and $\beta$-glucosidase at optimum conditions of each enzyme. Reported $\beta$-glucosidase from Bacillus pumilus $\mathrm{EB} 3^{15}$, the highest maximum activity of 0.038 units $/ \mathrm{mL}$ at $40^{\circ} \mathrm{C}$ and $\mathrm{pH} 4.8$.

Temperature and pH stability: Thermal stability of the enzyme endoglucanase produced by $1 \mathrm{M}-1$ isolates were incubated for $1-8 \mathrm{~h}$ at temperatures varying from 70 to $100^{\circ} \mathrm{C}$ is obtained, thermal stability of the enzyme at $80^{\circ} \mathrm{C}$ and was still be able to retain $80 \%$ of its activity after incubation up to $8 \mathrm{~h}$ (Fig. 5A) and in $\mathrm{pH}$ range of 6.0-7.0 (Fig. 5B), 1M-2 isolates can be retain $90 \%$ of its activity in the treatment incubation temperature of $70{ }^{\circ} \mathrm{C}$ in $6 \mathrm{~h}$ and $85 \%$ at $8 \mathrm{~h}$ (Fig. 6A) and in $\mathrm{pH}$ range of 7.0-7.5 (Fig. 6B ). 1M-3 isolates was still be able to retain $82 \%$ of its activity in the treatment incubation temperature of $80^{\circ} \mathrm{C}$ in $8 \mathrm{~h}$ (Fig. 7A) and in $\mathrm{pH}$ range 7.0-7.5 (Fig. 7B).

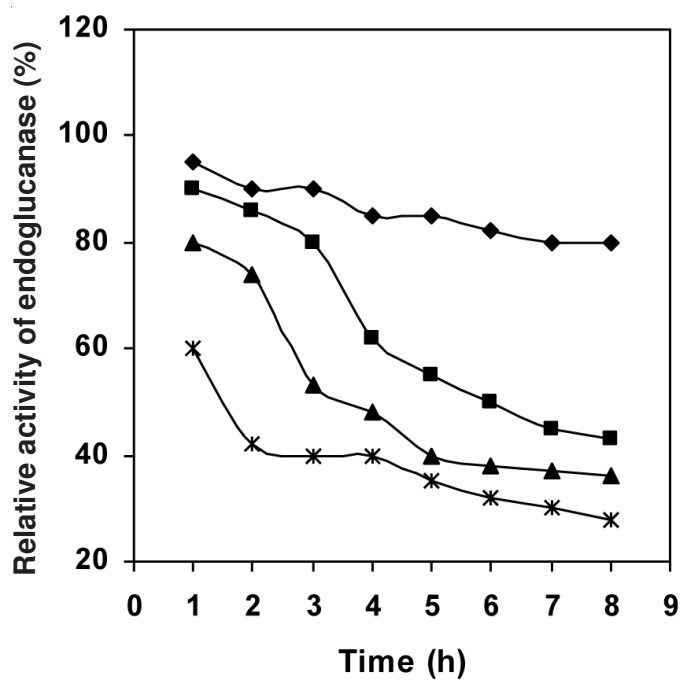

$\multimap-70^{\circ} \mathrm{C} \multimap 80^{\circ} \mathrm{C} \multimap 90^{\circ} \mathrm{C} \rightarrow-100^{\circ} \mathrm{C}$

A

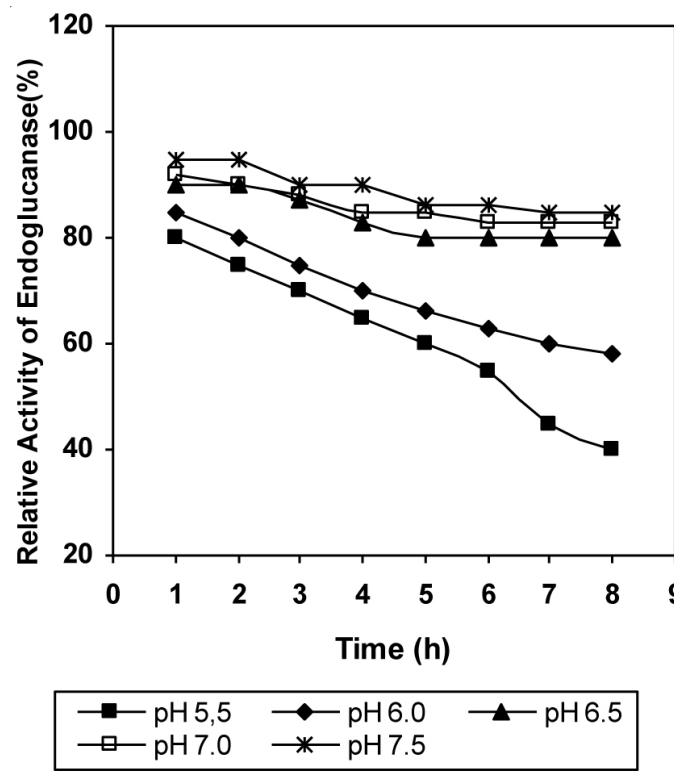

B

Fig. 5. Temperature (A) and $\mathrm{pH}$ (B) stability for $1 \mathrm{M}-1$ isolate. Endoglucanase activity was assayed (A). The enzymes was incubated in citrate buffer $\mathrm{pH} 4.8$ at $70-100{ }^{\circ} \mathrm{C}$ for $1-8 \mathrm{~h}$. Each activity treated at $70,80,90,100{ }^{\circ} \mathrm{C}$ for $0.5 \mathrm{~h}$ was taken as $100 \%$ and (B) at $\mathrm{pH}$ various of 4.5-9 used citrate buffer $(\mathrm{pH} 4.5-5.5)$, phosphate buffer ( $\mathrm{pH} 6.0-7.0)$ at $80^{\circ} \mathrm{C}$ and incubation time $0.5 \mathrm{~h}$ was taken as $100 \%$

\section{Conclusion}

Thermophilic bacteria isolated from hot springs Rambo Panti obtained 46 colonies and 14 isolates had cellulase activity (cellulolytic), three enzymes that act on the cellulolytic system, endoglucanase has the highest activity compared to, $\beta$ glucosidase and exoglucanase. Six isolates had high activity compared with pure cellulase enzyme from Aspergillus niger, for the 6 isolates assayed the effect of temperature and $\mathrm{pH}$ showed, endoglucanase tolerant of temperature and $\mathrm{pH}$ and shows broad stabilities of temperature and $\mathrm{pH}$, is expected to have potential application in the industry. 

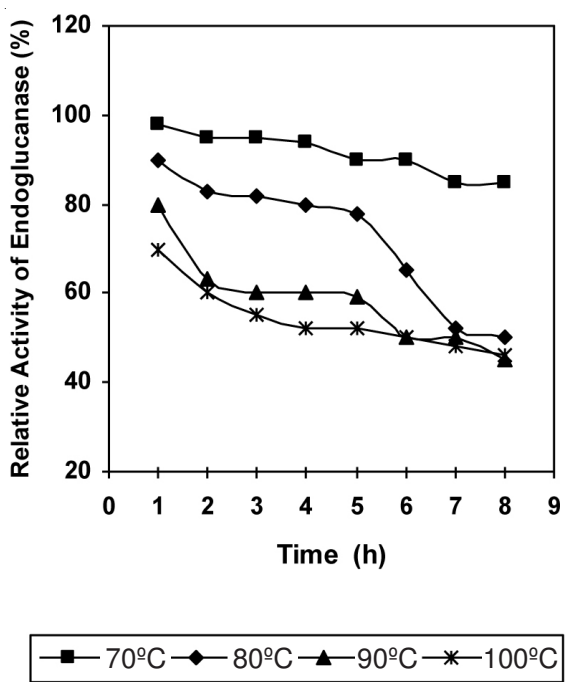

A

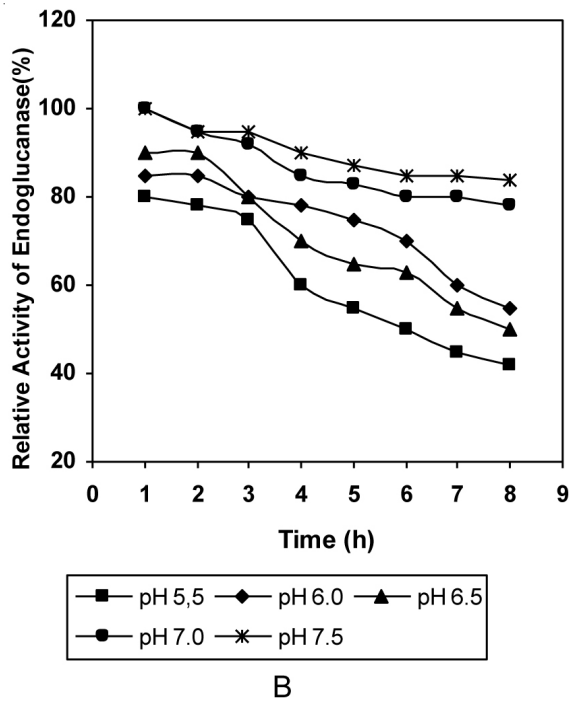

Fig. 6. Temperature (A) and $\mathrm{pH}$ (B) stability for $1 \mathrm{M}-2$ isolate. Endoglucanase activity was assayed (A). The enzymes was incubated in citrate buffer $\mathrm{pH} 4.8$, at $70-100{ }^{\circ} \mathrm{C}$ for $1-8 \mathrm{~h}$. Each activity treated at $70,80,90,100{ }^{\circ} \mathrm{C}$ for $0.5 \mathrm{~h}$ was taken as $100 \%$ and (B) at $\mathrm{pH}$ various of $4.5-9$ used citrate buffer $(\mathrm{pH} 4.5-5.5)$, phosphate buffer $(\mathrm{pH} 6.0-7.0)$ at $80{ }^{\circ} \mathrm{C}$ and incubation time $0.5 \mathrm{~h}$ was taken as $100 \%$

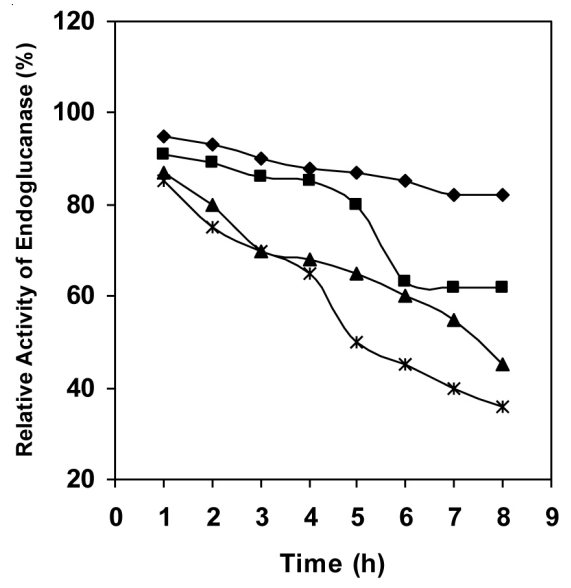

$\rightarrow 70^{\circ} \mathrm{C} \longrightarrow-80^{\circ} \mathrm{C} \longrightarrow-90^{\circ} \mathrm{C} \rightarrow-100^{\circ} \mathrm{C}$
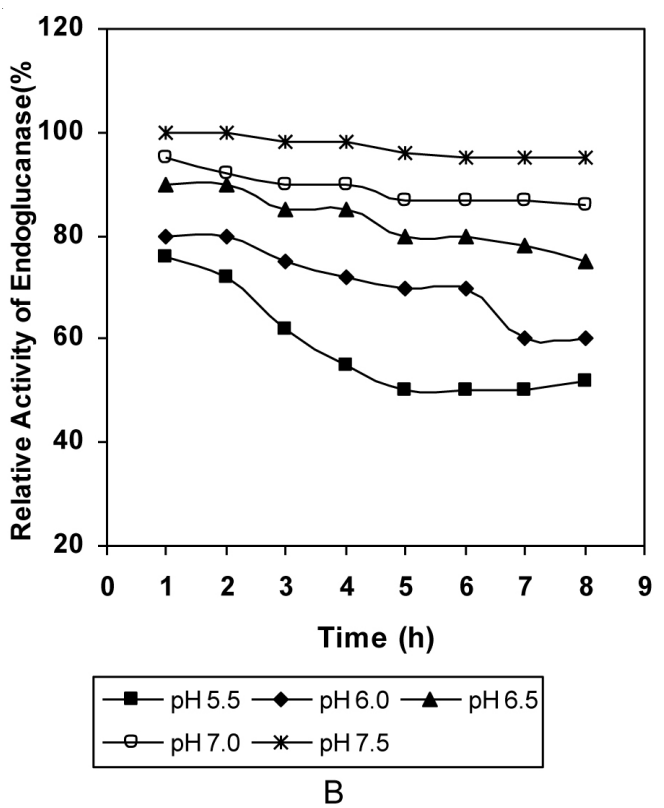

Fig. 7. Temperature (A) and pH (B) stability for 1M-3 isolate. Endoglucanase activity was assayed (A).The enzymes was incubated in citrate buffer $\mathrm{pH} 4.8$, at $70-100{ }^{\circ} \mathrm{C}$ for $1-8 \mathrm{~h}$. Each activity treated at $70,80,90,100{ }^{\circ} \mathrm{C}$ for $0.5 \mathrm{~h}$ was taken as $100 \%$ and (B) at $\mathrm{pH}$ various of 4.5 -9 used citrate buffer ( $\mathrm{pH} 4.5-5.5$ ), phosphate buffer (pH 6.0-7.0) at $80{ }^{\circ} \mathrm{C}$ and incubation time $0.5 \mathrm{~h}$ was taken as $100 \%$

\section{ACKNOWLEDGEMENTS}

One of the authors (Armaini) acknowledged with thanks to the Directorate General of Higher Education, Ministry of National Education and Culture of Indonesia, for the research funding in accordance with the Letter Agreement Implementation of Fundamental Research Assignment Number 169/ SP2H/PL/Dit.Litmas/IV/2011. April 14, 2011.

\section{REFERENCES}

1. Y. Nashida, K.I. Suzuki, Y. Kumagai, H. Tanaka, A. Inoue and T. Ojima, Biochemie, 89, 1002 (2007).

2. L.R. Lynd, P.J. Weimer, W.H. Zyl and I.S. Pretorius, Microbiol. Mol. Biol. Rev., 66, 506 (2002).

3. Y.J. Jung, Y.S. Lee, I.H. Park, M.S. Chandra, K.K. Kim and Y.L. Choi, Indian J. Biochem. Biophys., 47, 203 (2010).

4. W. Li, W.W. Zhang, M.M. Yang and Y.L. Chen, Mol. Biotechnol., 36, 195 (2008).

5. Y.-H.P. Zhang, M.E. Himmel and J.R. Mielenz, Biotechnol. Adv., 24, 452 (2006).

6. J. Hong, H. Tamaki, K. Yamamoto and H. Kumagai, Biotechnol. Lett., 25, 657 (2003).

7. G.D. Haki and S.K. Rakshit, Rev. Bioresour. Technol., 89, 17 (2003).

8. D. Yang, H. Weng, M. Wang, W. Xu, Y. Li and H. Yang, Mol. Biol. Rep., 37, 1923 (2009).

9. S.P. Paula, M. Alexandra, C.D. Jose, R. Maria, B. Aires and C.F. Maria, Enzym. Microbiol. Technol., 30, 924 (2002).

10. K.R. Sharrock, Rev. Biochem. Biophis. Methods, 17, 81 (1988).

11. T.K. Ghose, Pure Appl. Chem., 59, 257 (1987).

12. M. Mandel, R. Andreotti and C. Roche, Biotechnol. Bioeng. Symp, 6, 21 (1976).

13. M.M. Bradford, Anal. Biochem., 72, 245 (1976).

14. H. Ariffin, N. Abdullah, M.S. Umi Kalsom, Y. Shirai and M.A. Hasan, Int. J. Eng. Technol., 3, 47 (2006).

15. S. Acharya and A. Chaudary, J. Sci. Ind. Res., 70, 142 (2011).

16. M. Miyatake and K. Imada, Biosci. Biotechnol. Biochem., 61, 362 (1997). 